\title{
English Literature in Engineering Curriculum in India: Prospects and Perspectives
}

\author{
Dr. B. Bala Nagendra Prasad \\ Assistant Professor of English, Annamacharya Institute of Technology and Sciences, Rajampet, \\ Kadapa District, AP
}

*Corresponding Author: Dr. B. Bala Nagendra Prasad, Assistant Professor of English, Annamacharya Institute of Technology and Sciences, Rajampet, Kadapa District, AP

\begin{abstract}
It is widely acknowledged that literature has an essential association with life. Due to the ability of literature to hone creativity in language and imagination, its inclusion is essential in any system of education that promotes the importance of discovery as a vital feature of the learning process. The induction of literary content in English Language Teaching has been a popular practice for a long time. In ELT in India, English Literature continues to enjoy prime position and it has been a popular component of language courses in Indian School Education System. The addition of literature in ELT is to benefit students in three areas, namely language development, cultural and value enrichment and personal growth.
\end{abstract}

In ELT, literature is taught not only in primary and secondary schools in India but also in higher educational institutions such as Degree colleges. Higher educational institutions incorporate literature as a component of English language proficiency classes or as a subject for arts and language students. Its significance as part of the language syllabus in primary, secondary and higher educational institutions in India is undebatable.

In engineering institutions, the educators aim to equip the students with the capacity to think independently, creatively and passionately for life-long learning. However, the new challenges, sprung up in the realm of engineering and technology across the world, created an urgent need to make engineering education more relevant to the times.

A college student in general, an engineering undergraduate in particular undergoes various influencing factors during his college life and his personality is moulded during this crucial period. $\mathrm{He}$ is required to perform intellectually all the time and many a student gets bewildered and suffers through frequent bouts of depression and, sometimes, may end his life. Not every student is privy to counseling at this level.

Students joining engineering institutions right out of intermediate course, experience dramatic and drastic change in their life. The young minds are subject to listening technical lectures, performing experiments in laboratories for eight hours a day. The students are required to perform quietly and correctly. Recreational hours are almost nil, excepting English class.

English language course is prescribed only in the first year of engineering education. The prescribed syllabus is divided into four parts, namely Listening, Reading, Writing and Grammar. The writing does not allow for much creativity as the context of which is mostly technical. Students write letters, checklists, safety instructions, reports and the like. The comprehension passages and grammatical structures are also related to technology.

\section{WHY STUDY LITERATURE?}

A work of literature imitates life. Characters in literary texts reflect the times and they have their own individuality, their strengths and weaknesses. The study of the beliefs and attitudes of characters lead to a better understanding of human nature. The knowledge and truth afforded by literature are different from the knowledge and truth provided by history and science. From this point of view, a 
literary work affects people. It stirs their feeling, raises their emotions and changes their ideas and mindset.

Literature is a privileged form of human activity because no other human activity brings out, fully or precisely, the variety, possibility or complexity of human life.

More importantly, Literature should be studied for a richer life, as it is entertaining, meaningful, funny, or tragic. They can convey profundity of thought, richness of emotion, and insight into character. Literature takes us beyond our limited experience of life to show us the lives of other people. Literature stirs us intellectually and emotionally, and deepens our understanding of our history, our society, and our own individual lives. By reading literary texts, discussing the plot with others, thinking about how they would react in similar situations, students will learn and study human condition.

Literature is language in its finest form. That is why, studying literature encourages the learner towards language acquisition, expands the students' language awareness, and develops their interpretative abilities.

Engineering students work industriously for four years and obtain the necessary technical knowledge and skills that enable them to get employment. But the human soul inside them is not nourished. The students, upon becoming employees of a company, feel hopeless and unable to deal with the imminent crises, emotional, professional and otherwise. Engineering colleges are successful in making the students ready for industry, not for life.

We are living in a pervasive globalized environment. The incorporation of English literature develops a cultural and intercultural understanding in the engineering students who are expected to work in a heterogeneous environment. Also, it needs to be noted that literature deals with diverse concepts endemic to human condition - family, relationships, business, finance, patriotism and so on. An engineering graduate will be able to identify with such concepts and develops his personality.

Cleanth Brooks et al. say "Literature gives a picture of life-not the picture that is actually (historically) true, but a picture that has its own kind of truth-a 'truth' that includes important elements that science from its very nature is forced to leave out. The truth of literature takes the form, not of abstract statement but of a concrete and dramatic presentation, which may allow us to experience imaginatively the 'lived' meanings of a piece of life."

The author, being an English teacher in an Engineering College for the past ten years, strongly feels that inclusion of literary context in English syllabus will enhance the quality of engineering students. The researcher feels that it is highly important to balance the learning of Listening, Speaking, Reading and Writing skills in English with the study of Literature. As the existing syllabus in most of the technical universities is devoid of the spirit of humanity and given the fact that technical students are not given the opportunity to study English Literature as part of the curriculum, the relevance of a subject like English Literature to engineering students is one factor to be scrutinized upon and exposure to English literary texts will definitely serve the purpose of sensitizing the technical students with life-long and value-based learning.

The author would like to note that while much research has been done to evaluate the relevance of teaching literature as part of English language course at school level, there is dearth of research that focuses on inclusion of English literature at engineering colleges.

Also, there has not been much research conducted with regard to the perception of technical students and the English teachers in technical institutions. It is therefore vital to embark on research focused in the areas mentioned above, given the lack of research undertaken in this area.

At this juncture, the author would like to note that perception of technical learners on the inclusion of literature in English programmes in engineering curriculum is an area of research that needs to be tapped further.

As literary texts offer a rich source of linguistic input, the author is of the opinion that they will create opportunity for engineering students to practice four skills of language learning- speaking, listening, reading and writing-in addition to emphasizing grammatical structures and presenting new vocabulary. 


\section{REFERENCES}

[1] O' Sullivan, R. Literature in the language classroom. The English Teacher. 1991

[2] Cleanth Brooks, et. al. An Approach to Literature. New York: Crofts. 1942.

\section{AUTHOR's BIOGRAPHY}

Dr. B. Bala Nagendra Prasad, holds $\mathrm{PhD}$ in English Literature from JNTU Anantapuramu. Currently, he is working as Head, Dept. of HS at Annamacharya Institute of Technology and Sciences (Autonomous) Rajampet, AP, India.

Citation: Nagendra Prasad, B. Bala. "English Literature In Engineering Curriculum In India: Prospects And Perspectives." International Journal On Studies In English Language And Literature (IJSELL), vol 5, no. 11, 2017, pp. 1-3. doi:http://dx.doi.org/10.20431/2347-3134.0511001.

Copyright: (C) 2017 Authors. This is an open-access article distributed under the terms of the Creative Commons Attribution License, which permits unrestricted use, distribution, and reproduction in any medium, provided the original author and source are credited. 